\title{
EFFECT OF CYANOBACTERIAL PEPTIDES AND PROTEINS ON COAGULATION OF KAOLINITE
}

\author{
KATEŘINA NOVOTNÁ1,2, MAGDALENA BAREŠOVÁ ${ }^{1,3}$, LENKA ČER- \\ MÁKOVÁ ${ }^{1,3}$, JANA NAČERADSKÁ ${ }^{1,3}$, and MARTIN PIVOKONSKÝ $1,3, *$
}

\author{
${ }^{1}$ Institute of Hydrodynamics, Academy of Sciences of the Czech Republic, Pod Patankou 30/5, 16612 Prague 6, Czech Republic \\ ${ }^{2}$ Department of Water Technology and Environmental Engineering, University of Chemistry and Technology, Prague, Technická 5 , \\ 16628 Prague 6, Czech Republic \\ ${ }^{3}$ Institute for Environmental Studies, Faculty of Science, Charles University, Benátská 2, 12801 Prague 2, Czech Republic \\ * Corresponding author: pivo@ih.cas.cz
}

\section{ABSTRACT}

Coagulation of peptides and proteins produced by the cyanobacterium Microcystis aeruginosa and their influence on the coagulation of hydrophobic kaolinite particles were investigated. For this purpose, the dose of ferric sulphate used as the coagulant was optimized and jar tests with kaolinite, peptides/proteins and both kaolinite and peptides/proteins were carried out under different $\mathrm{pH}$ conditions. At pH $4-5.5$, the peptides/proteins were efficiently coagulated and peptides/proteins were also found to contribute to the coagulation of kaolinite particles at this $\mathrm{pH}$. Charge neutralization and adsorption were found to be the dominant coagulation mechanisms. The coagulation efficiency and the character of the prevailing coagulation mechanism were strongly dependent on the charge characteristics of the peptides/proteins, kaolinite and hydrolysis products of iron, thus on the $\mathrm{pH}$ value. At a $\mathrm{pH}$ of about 6 , the coagulation process deteriorated due to the formation of soluble Fe-peptide/protein complexes.

Keywords: cellular organic matter (COM), coagulation, complex formation, Microcystis aeruginosa, water treatment

\section{Introduction}

Eutrophication of surface waters leads to seasonal occurrence of algal blooms and excess growth of cyanobacteria. Algal organic matter (AOM) interferes with the water treatment process, which includes a reduction in the coagulation efficiency resulting in increased coagulant demand (Bernhardt et al. 1985; Takaara et al. 2007; Ma et al. 2012), membrane fouling (Campinas and Rosa 2010), higher production of hazardous disinfection by-products (Huang et al. 2009; Fang et al. 2010) and disagreeable odour and taste compounds (Li et al. 2012). Cyanobacteria, usually a prevailing component of algal blooms, also produce many toxins (Harada 2004). The current knowledge of the influence of AOM on water quality and the water treatment processes are reviewed in detail by Pivokonsky et al. (2016). AOM includes extracellular organic matter (EOM) derived from the metabolic activity of algae and cellular organic matter (COM) released when cells are damaged. COM is released into water at higher rates when pre-oxidation methods are used to enhance the coagulation of algal cells ( $\mathrm{Ma}$ et al. 2012; Xie et al. 2013) and especially during the decay of algal blooms, which usually lead to a sudden decrease in coagulation efficiency (Pivokonsky et al. 2009a). This could be temporarily overcome by increasing coagulant dose. However, this generates subsidiary problems, e.g. an increase in operating cost and yield of sludge.

COM includes a wide spectrum of substances such as oligosaccharides, polysaccharides, proteins, peptides, amino acids and some other organic acids (Lüsse et al. 1985; Maksimova et al. 2004). In general, the composition of COM can be characterized as non-protein and protein organic matter (Pivokonsky et al. 2006). Some studies have demonstrated that, for instance, proteins produced by the cyanobacterium Microcystis aeruginosa during its stationary growth phase make up about 60-65\% of its COM (Pivokonsky et al. 2006; Henderson et al. 2008). As a result of the release of COM during algal growth, there are increasing amounts of proteins in the cultivation media of several species. The peptide/ protein portion reached up to $47 \%$ of the total organics for Microcystis aeruginosa, $42 \%$ for the diatom Fragilaria crotonensis and $28 \%$ for the green alga Chlamydomonas geitleri (Pivokonsky et al. 2014).

COM peptides and proteins may have either a positive or negative effect on coagulation. They can improve coagulation by acting as polymer aids under specific conditions (Bernhardt et al. 1985; Ma et al. 2012). On the other hand, COM peptides and proteins may adversely affect the coagulation process and increase the consumption of coagulant by forming soluble complexes with metal ions (Fe and Al) used as coagulants (Pivokonsky et al. 2006, 2012; Takaara et al. 2007). In addition, COM influences the coagulation of other impurities present in inpurified water, e.g. inorganic colloids or humic substances (HS). The COM peptides/proteins produced by M. aeruginosa can enhance coagulation of humic substances if the process is operated within a certain $\mathrm{pH}$ range. The positive effect occurs due to electrostatic, hydrophobic and 
dipole-dipole interactions between proteins and HS (Pivokonsky et al. 2015). Some studies have also revealed the effect of AOM components on coagulation of quartz (Bernhardt et al. 1985) or kaolin particles (Takaara et al. 2007, 2010). However, the effect of reaction conditions ( $\mathrm{pH}$, coagulant dose etc.) and the character of COM (molecular weight, surface charge of molecules, functional group content etc.) on coagulation of particulate impurities has not been adequately explained. Therefore, this study is aimed at the elucidation of the effect of COM peptides/proteins (isolated from cyanobacterium Microcystis aeruginosa) on the coagulation of a hydrophobic kaolinite suspension and description of the mechanisms of the interactions between peptides/proteins, kaolinite particles and hydrolysis products of the coagulant.

\section{Materials and Methods}

\section{Kaolinite Samples}

The kaolinite clay (particles $<4 \mu \mathrm{m}$ ) was obtained from the deposit at Sedlec (Sedlecky kaolin a.s., Czech Republic). Aqueous suspension of kaolinite particles was homogenized using an ultrasonic homogenizer (UP400S, Hielscher Ultrasonics, Germany) at $100 \%$ amplitude of ultra-sonication $(400 \mathrm{~W})$ in pulse mode for $30 \mathrm{~min}$, and subsequently used in coagulation experiments.

\section{Kaolinite Surface Charge Determination}

The surface charge of kaolinite was determined using potenciometric titrations performed at three electrolyte concentrations. Specifically, $40 \mathrm{~g}$ of kaolinite clay $(<4 \mu \mathrm{m})$ was mixed with $1.0,0.1$ and $0.01 \mathrm{M}$ solutions of $\mathrm{NaCl}$ so that the final volume was $400 \mathrm{ml}$. The samples were homogenized using an ultrasonic homogenizer (UP400S, Hielscher Ultrasonics, Germany) at 100\% amplitude of ultra-sonication $(400 \mathrm{~W})$ in pulse mode for $30 \mathrm{~min}$. Then, $0.1 \mathrm{M} \mathrm{NaOH}$ was added to obtain an initial $\mathrm{pH}$ of 12 and the samples were titrated with $0.1 \mathrm{M} \mathrm{HCl}$ to pH 2.5 in a nitrogen atmosphere using an Orion $960 \mathrm{Au}-$ totitrator (Thermo Scientific, USA). Blank titrations were also performed. Relative surface charge was determined from the difference between the surface titration curves and the blank curves. Relative surface charge was then plotted against $\mathrm{pH}$. The $\mathrm{pH}$ at which the curves of three electrolyte concentrations crossed was the $\mathrm{pH}$ at which kaolinite particles exhibit zero net charge at the surface ( $\mathrm{pH}$ of point of zero charge, i.e. $\mathrm{pH}_{\mathrm{pzc}}$ ). This method is described in detail in the literature (van Raij and Peech 1972; Coles and Yong 2002).

\section{COM peptide/protein preparation}

Cyanobacterium Microcystis aeruginosa used in this study was harvested at the Svihov water reservoir (Czech Republic). Sampling was done using a plankton net with a mesh size of $0.01 \mathrm{~mm}$. The sampled cells were separat- ed from coarse impurities by washing in ultra-pure water and passing the sample through a sieve with mesh size of $0.1 \mathrm{~mm}$. Subsequently, the cells were separated from water by filtration through $0.22 \mu \mathrm{m}$ membrane filter (Millipore, USA). Quantitative microscopic analysis of the separated cells showed that samples consisted of approximately $99 \%$ M. aeruginosa. Thereafter, the cells were stirred with ultra-pure water and disrupted in an ice bath using an ultrasonic homogenizer (UP400S, Hielscher Ultrasonics, Germany) at $60 \%$ amplitude of ultra-sonication $(240 \mathrm{~W})$ in pulse mode for $5 \mathrm{~min}$. The residual solids were removed by centrifugation and subsequently by a $0.22 \mu \mathrm{m}$ membrane filter (Millipore, USA). Peptides/ proteins were isolated from the COM using $\left(\mathrm{NH}_{4}\right)_{2} \mathrm{SO}_{4}$ to precipitate protein (Dawson et al. 1986). The peptide/ protein precipitate was then separated from the non-protein organic matter by filtration through a $0.22 \mu \mathrm{m}$ membrane filter (Millipore, USA), dissolved in $200 \mathrm{ml}$ of ultra-pure water and purified using an ultrafiltration membrane PLAC 1000 Da (Millipore, USA) and a Solvent Resistant Stirred Cell (Millipore, USA).

\section{COM peptide/protein characterization}

Dissolved organic carbon (DOC) concentration was monitored in samples filtered through $0.22 \mu \mathrm{m} \mathrm{mem-}$ brane filter (Millipore, USA) using a Shimadzu TOC$\mathrm{V}_{\mathrm{CPH}}$ analyzer (Shimadzu Corporation, Japan) that measured the organic carbon content by the TC-IC method as the difference between TC (total carbon) and IC (inorganic carbon). The average DOC value for each sample was determined from three measurements and the error was less than $2 \%$.

Apparent molecular weights (MW) of COM peptides/ proteins were determined by high performance size exclusion chromatography (HPSEC) using the method described in the literature (Hnatukova et al. 2011; Pivokonsky et al. 2012). Reproducibility of the MW fractionation of COM protein samples was very good, with MW deviations of less than $3 \%$ between repeated measurements.

Isoelectric points ( $\mathrm{pI}$ ) of COM peptides/proteins were determined by isoelectric focusing (IEF) using a Multiphor II electrophoresis system (Pharmacia, Sweden) according to the method described in the literature (Hnatukova et al. 2011).

Peptides/proteins, which are able to form soluble complexes with iron, were isolated by affinity chromatography. The samples of peptides/proteins were passed through an affinity column ( $1 \mathrm{ml}$ HiTrap $^{\mathrm{TM}}$, Amersham Bioscience Corp., Japan) in which $\mathrm{Fe}^{3+}$ ions were immobilized as ligands. Binding buffer was prepared with $0.02 \mathrm{M}$ sodium phosphate and $0.5 \mathrm{M} \mathrm{NaCl}(\mathrm{pH}$ 6). Elution buffer was of the same composition as the binding buffer, but its $\mathrm{pH}$ was set to 9. The elution strategy was developed in order not to damage peptides/proteins and prepare a sample suitable for UV detection. The flow rate of buffer was $1 \mathrm{ml} \mathrm{min}^{-1}$ and the volume of the fractions 
collected was $15 \mathrm{ml}$. Then, the eluted fractions were desalted and concentrated using an ultrafiltration membrane PLAC $1000 \mathrm{Da}$ (Millipore, USA) and a Solvent Resistant Stirred Cell (Millipore, USA). MWs of isolated peptides/proteins were determined using HPSEC. All analyses were done in triplicate.

\section{Coagulation Tests}

The influence of COM peptides/proteins on the coagulation process was investigated using standard jar tests (Bratby 2006). Jar testing was done with a variable speed eight paddle stirrer LMK 8-03 (IH AS CR, Czech Republic) in 21 jars. Ferric sulphate (Sigma-Aldrich, USA) was used as a coagulant because the study of Pivokonsky et al. (2009b) has shown that its efficiency in COM peptide/ protein coagulation is higher than that of aluminium coagulants. Its optimum dose for efficient peptide/protein removal was determined by using tests without $\mathrm{pH}$ control and with coagulant doses ranging from 0.025 to $0.250 \mathrm{mmol} \mathrm{l}^{-1}$ of $\mathrm{Fe}\left(1.4-14.0 \mathrm{mg} \mathrm{l}^{-1}\right)$. For experiments in which the $\mathrm{pH}$ was controlled and coagulant dose optimized, $0.1 \mathrm{M} \mathrm{HCl}$ and $0.1 \mathrm{M} \mathrm{NaOH}$ were added to achieve the target $\mathrm{pH}$ varying between 3 and 9. The jar test procedure consisted of 1 minute of high intensity agitation $\left(G=300 \mathrm{~s}^{-1}\right), 15$ minutes of low intensity agitation $\left(G=80 \mathrm{~s}^{-1}\right)$ and 60 minutes of settling. The results of coagulation tests were evaluated by water analysis after sedimentation of the suspension. Residual Fe, dissolved organic carbon (DOC), turbidity, $\mathrm{pH}$, alkalinity and molecular weight of residual peptides/proteins were monitored. In order to evaluate the influence of COM peptides/proteins on coagulation of kaolinite suspension, three types of jar tests were operated within the $\mathrm{pH}$ range 3-9 using the optimum coagulant dose of $7 \mathrm{mg} \mathrm{l}^{-1}$, i.e. $0.125 \mathrm{mmol} \mathrm{l}^{-1}$ of Fe. Moreover, the comparison of jar testing results enabled the description of probable coagulation mechanisms. To facilitate the comparison between different types of jar tests, the optimum dose for peptide/ protein removal was also used in other types of jar tests. The jar tests were as follows:

1) coagulation of suspended kaolinite particles,

2) coagulation of COM peptides/proteins,

3) coagulation of suspended kaolinite particles together with COM peptides/proteins.

The corresponding samples of synthetic raw water were used:

1) Ultra-pure water with an alkalinity of $1.5 \mathrm{mmol} \mathrm{l}^{-1}$ $\left(75 \mathrm{mg} \mathrm{l}^{-1} \mathrm{CaCO}_{3}\right.$ ) with $\mathrm{NaHCO}_{3}+25 \mathrm{mg} \mathrm{l}^{-1}$ of kaolinite particles $<4 \mu \mathrm{m}$.

2) Ultra-pure water with an alkalinity of $1.5 \mathrm{mmol} \mathrm{l}^{-1}$ (75 mg ${ }^{-1} \mathrm{CaCO}_{3}$ ) with $\mathrm{NaHCO}_{3}+\mathrm{COM}$ peptides/ proteins of DOC concentration $8 \mathrm{mg} \mathrm{l}^{-1}$.

3) Ultra-pure water with an alkalinity of $1.5 \mathrm{mmol} \mathrm{l}^{-1}$ $\left(75 \mathrm{mg} \mathrm{l}^{-1} \mathrm{CaCO}_{3}\right)$ with $\mathrm{NaHCO}_{3}+25 \mathrm{mg} \mathrm{l}^{-1}$ of kaolinite particles $<4 \mu \mathrm{m}+\mathrm{COM}$ peptides/proteins of DOC concentration $8 \mathrm{mg} \mathrm{l}^{-1}$.
DOC concentration of $8 \mathrm{mg} \mathrm{l}^{-1}$ is the common COM peptide/protein content in natural surface water (Pivokonska et al. 2008).

\section{Results and Discussion}

\section{COM Peptide/Protein Characterization}

The COM peptides/proteins were characterized in terms of MW distribution. Fig. 1 shows peptides/proteins isolated from COM produced by the cyanobacterium $M$. aeruginosa of apparent MWs of 1, 2.8, 4, 4.5, 5, $5.7,6,6.8,8,8.5,12,30,40,52,106,266,470$ and 1077 $\mathrm{kDa}$. The values of peptide/protein isoelectric points (pI) determined by isoelectric focusing (IEF) were 4.79, 5.12, $5.25,5.45,5.62,5.80,6.10,6.33,6.47,6.63,7.05,7.39$, $7.82,7.93$ and 8.05 . The character of COM peptides/proteins of $M$. aeruginosa has been discussed in our previous studies (Pivokonsky et al. 2006, 2012, 2014; Hnatukova et al. 2011).

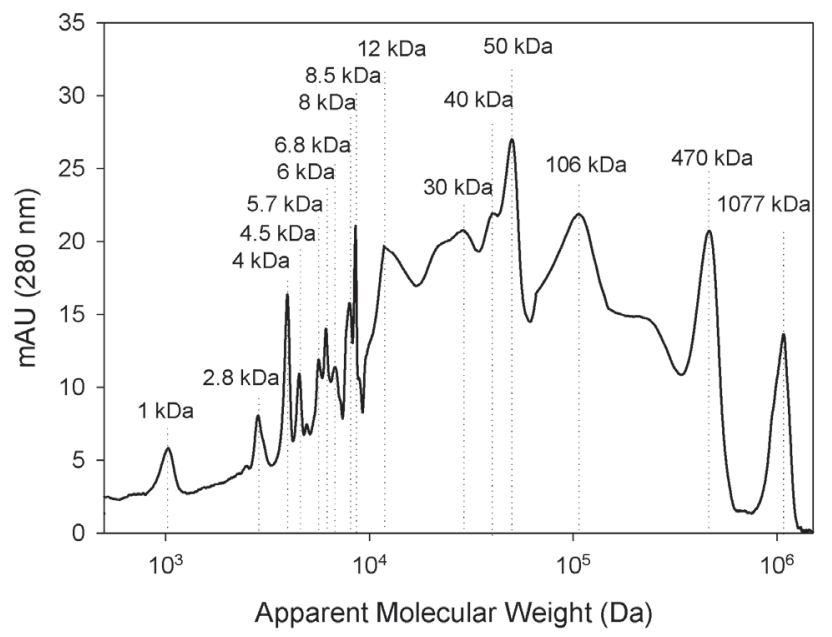

Fig. 1 HPSEC profile of COM peptides/proteins.

\section{Coagulation of Kaolinite Suspension}

Fundamental mechanisms of kaolinite coagulation are charge neutralization and adsorption (Bache and Gregory 2007). Their efficiency is closely related to the surface charge value (of both kaolinite particles and hydrolysis products of coagulation agent), which is $\mathrm{pH}$ dependent. As for ferric hydroxocomplexes, at $\mathrm{pH}<2$, $\mathrm{Fe}^{3+}$ ions occur in a water environment as Fe-hexaaquacomplex $\left[\mathrm{Fe}\left(\mathrm{H}_{2} \mathrm{O}\right)_{6}\right]^{3+}$. At $\mathrm{pH} \sim 2$, double nuclear Fe-hydroxocomplex $\left[\mathrm{Fe}_{2}(\mathrm{OH})_{2}\right]^{4+}$ ions are formed due to the release of protons from the ion. As the $\mathrm{pH}$ rises $(\mathrm{pH}>2)$, hydrolysis proceeds and the positively charged polynuclear Fe-hydroxopolymers (i.e. $\left[\mathrm{Fe}_{2}(\mathrm{OH})_{3}\left(\mathrm{H}_{2} \mathrm{O}\right)_{7}\right]^{3+}$, $\left[\mathrm{Fe}_{2}(\mathrm{OH})_{4}\left(\mathrm{H}_{2} \mathrm{O}\right)_{5}\right]^{5+}$ and $\left.\left[\mathrm{Fe}_{4}(\mathrm{OH})_{6}\left(\mathrm{H}_{2} \mathrm{O}\right)_{12}\right]^{6+}\right)$ and Fe-oxide-hydroxides $a-\mathrm{FeO}(\mathrm{OH})$ or $\gamma$ - $\mathrm{FeO}(\mathrm{OH})$ are formed. At $\mathrm{pH}>8$, iron largely occurs as anionic hydroxocomplexes, e.g. $\left[\mathrm{Fe}(\mathrm{OH})_{4}\right]^{-}$(Stumm and Morgan 1996). The surface charge of a kaolinite suspension, specifically 
its point of zero charge $\left(\mathrm{pH}_{\mathrm{pzc}}\right)$, depends on the chemical composition of kaolinite. In this study, $\mathrm{pH}_{\mathrm{pzc}}$ was determined by potentiometric titrations at three different electrolyte concentrations $(0.01,0.1$ and $1.0 \mathrm{M} \mathrm{NaCl})$ and was set to approximately $\mathrm{pH}=3$. It implies that negatively charged sites on the kaolinite surface prevail at $\mathrm{pH}>3$ and that the total kaolinite charge is negative.

The coagulation tests performed with aqueous suspension containing $25 \mathrm{mg} \mathrm{l}^{-1}$ of kaolinite particles and with an iron dose of $7 \mathrm{mg} \mathrm{l}^{-1}$ (i.e. $0.125 \mathrm{mmol} \mathrm{l}^{-1} \mathrm{Fe}$ ) showed that the lowest residual concentrations of both kaolinite (expressed as residual turbidity) and iron were reached in the $\mathrm{pH}$ range 6.5 to 8 (Fig. 2). Very similar results for kaolinite coagulation are reported by Kim and Kang (1998) who recorded the highest kaolinite removal by ferric nitrate (initial kaolinite concentration $25 \mathrm{mg} \mathrm{l}^{-1}$ ) at a $\mathrm{pH}$ between 6.7 and 8.2. Within this $\mathrm{pH}$ range, positively charged iron hydroxocomplexes and iron oxides-hydroxides are adsorbed on negatively charged kaolinite particles, which results in a gradual neutralization of the kaolinite surface charge and efficient coagulation. Adsorption of iron constituents is explained by electrostatic interactions, exchanging reactions and hydrogen bonding (Bache and Gregory 2007).

\section{Coagulation of COM Peptides and Proteins}

The results of coagulation tests with peptides/proteins (DOC $8 \mathrm{mg} \mathrm{l}^{-1}$ ) and ferric sulphate $\left(7 \mathrm{mg} \mathrm{l}^{-1}=\right.$ $0.125 \mathrm{mmol} \mathrm{l}^{-1}$ of $\mathrm{Fe}$ ) are shown in Fig. 3. The lowest residual peptide/protein concentration (expressed as residual DOC concentration) was achieved within the $\mathrm{pH}$ range 4 to 6 . The capability of COM peptides/proteins to be coagulated stems depended on the character and content of functional groups and also their molecular weight, which will be discussed later. Some of the functional groups, such as $-\mathrm{OH},-\mathrm{COOH},-\mathrm{SH},-\mathrm{NH}_{2},-\mathrm{CONH}_{2}$ etc. may bear a charge under certain $\mathrm{pH}$ conditions, which allows coagulation by charge neutralization and/ or adsorption (Bernhardt et al. 1985). If the isoelectric

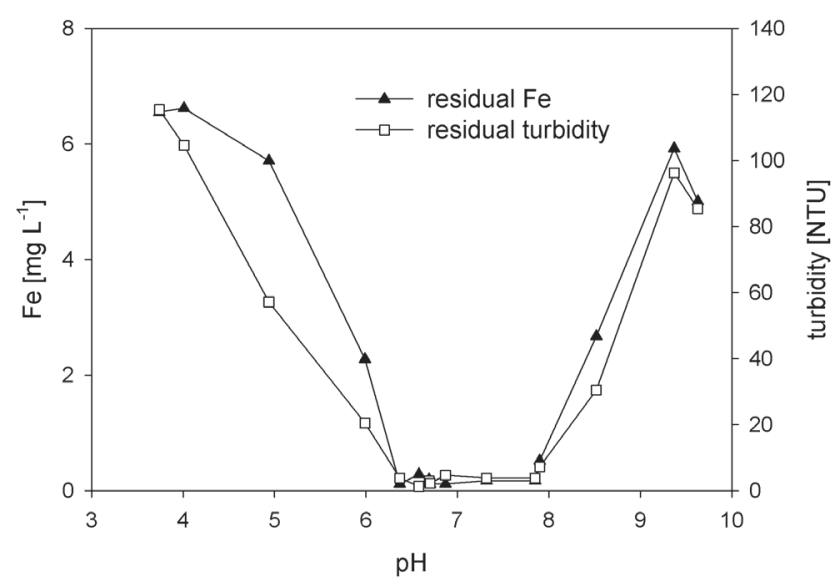

Fig. 2 Jar tests with kaolinite - dependence of residual Fe and turbidity on $\mathrm{pH}$ value $\left(\mathrm{D}_{\mathrm{Fe}}=7 \mathrm{mg} \mathrm{l}^{-1}\right)$. points of peptides/proteins are taken into consideration, it is obvious that at the $\mathrm{pH}$ of the highest coagulation efficiency (4-6), peptides/proteins bear both negatively and positively charged functional groups on their surface. They are therefore able to interact electrostatically with positively charged hydrolysis products of iron. At $\mathrm{pH}$ around 6, a noticeable increase in residual DOC and iron concentration was recorded, which means that a portion of the peptides/proteins and iron remained in solution owing to the formation of soluble Fe-peptide/ protein surface complexes. Our previous study (Pivokonsky et al. 2012) showed that the mechanisms of Fe-peptide/protein complex formation are largely of electrostatic character and that the ability of peptides/proteins to form complexes with $\mathrm{Fe}$ (i.e. their binding capacity) is dependent on $\mathrm{pH}$. It reaches its maximum at $\mathrm{pH}$ 6-7. Naturally, if Fe ions are bound to peptides/proteins, they cannot take part in the coagulation process (Bernhardt et al. 1985; Pivokonsky et al. 2006; Takaara et al. 2007). Moreover, iron bound to peptides/proteins blocks negatively charged sites on the peptide/protein surface, which prevents peptides/proteins from being coagulated by adsorption and charge neutralization mechanisms (Pivokonsky et al. 2012). As seen in Fig. 3, residual DOC and Fe concentrations sharply increased at $\mathrm{pHs}>7$. At this $\mathrm{pH}$ value, the negative charge of both hydrolysis products of iron and peptides/proteins prevails and thus, repulsive electrostatic interactions lead to inefficient coagulation.

In order to characterize peptides/proteins able to form soluble complexes with iron, affinity chromatography followed by HPSEC was performed. Fig. 4 shows that complex forming peptides/proteins have MWs of 1, 2.8, $6,8,8.5,10$ and $52 \mathrm{kDa}$. It is well known that cyanobacterial COM may contain several groups of metal binding compounds. The low-MW region probably includes iron-binding peptides of MW of 500-1500 Da called siderophores, which are secreted by cyanobacteria under conditions of iron stress and enable the transport of ferric ions into cells (Albrecht-Gary and Crumbliss 1998). In addition, low-MW compounds might be cyanobacteri-

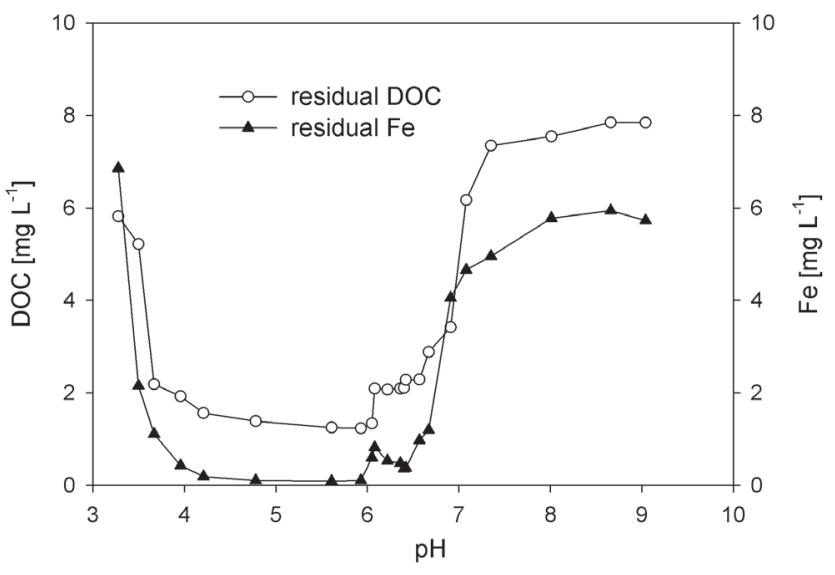

Fig. 3 Jar tests with peptides/proteins - dependence of residual DOC and $\mathrm{Fe}$ on $\mathrm{pH}$ value $\left(\mathrm{D}_{\mathrm{Fe}}=7 \mathrm{mg} \mathrm{l}^{-1}\right)$. 


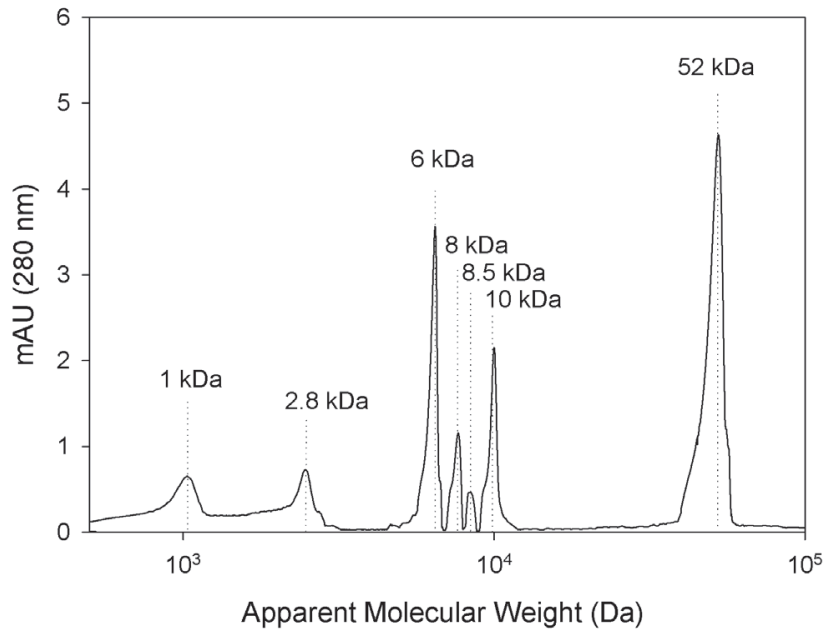

Fig. 4 HPSEC profile of complex forming peptides/proteins.

al metallothioneins, cysteine-rich peptides/proteins that bind, sequester and buffer the excess intracellular metal cations through the thiol group of its cysteine residues (Turner and Robinson 1995). The isolated iron-binding protein of MW $52 \mathrm{kDa}$ probably is the cyanobacterial metalloenzyme bidirectional hydrogenase, which has an affinity for iron and is present in M. aeruginosa (Tamagnini et al. 2007). Fe-binding protein of a similar molecular weight was also isolated in several other studies (Pivokonsky et al. 2006, 2012; Takaara et al. 2007).

\section{Coagulation of Kaolinite Together with COM Peptides and Proteins}

Coagulation tests with kaolinite $\left(25 \mathrm{mg} \mathrm{l}^{-1}\right)$, peptides/ proteins (DOC $8 \mathrm{mg} \mathrm{l}^{-1}$ ) and ferric sulphate $\left(7 \mathrm{mg} \mathrm{l}^{-1}\right.$ $=0.125 \mathrm{mmol} \mathrm{l}^{-1}$ of $\mathrm{Fe}$ ) revealed that the optimum $\mathrm{pH}$ conditions were within almost the same range as the above described coagulation tests with peptides and proteins. Kaolinite particles, peptides/proteins and iron were efficiently removed at pHs between 4 and 5.5 (Fig. 5). As the $\mathrm{pH}$ value rose, the DOC removal efficiency decreased and the peptide/protein coagulation ceased at $\mathrm{pH}$ about 7. Further, Fig. 5 also shows that the removability of kaolinite particles is closely connected with the coagulation of COM peptides/proteins. In the presence of these organic substances, kaolinite was removed even at $\mathrm{pHs}$ $<5.5$. However, as demonstrated before, kaolinite particles were not removed within this $\mathrm{pH}$ range in the absence of peptides/proteins. The probable mechanisms involved in the coagulation of peptides/proteins and kaolinite are again charge neutralization and adsorption. At $\mathrm{pHs}$ $<5.5$, not only electrostatic interactions between positively charged iron hydroxocomplexes and negatively charged ionized functional groups of peptides/proteins occur (as described for coagulation of peptides/proteins), but there are also electrostatic interactions between positively charged peptide/protein functional groups (e.g. $-\mathrm{NH}_{3}{ }^{+}$) and negatively charged kaolinite particles. These interactions lead to the gradual neutralization of

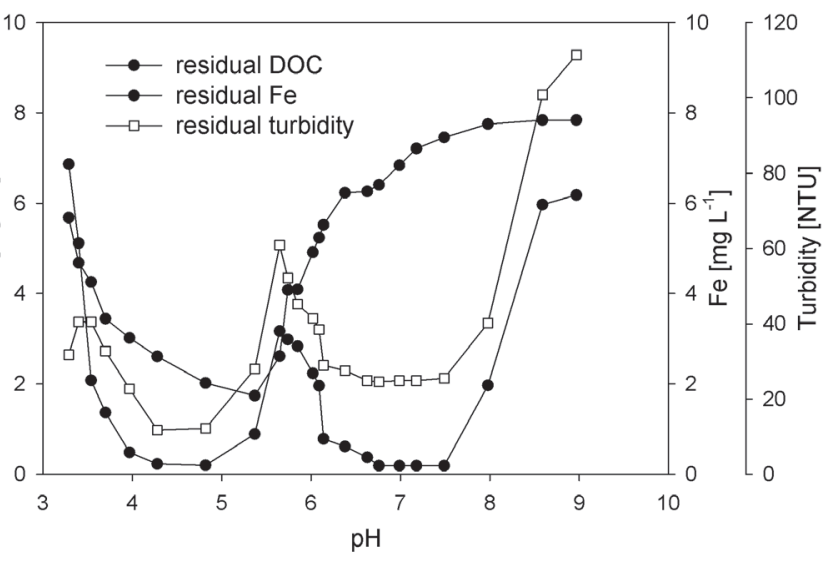

Fig. 5 Jar tests with kaolinite + peptides/proteins-dependence of residual $\mathrm{DOC}, \mathrm{Fe}$ and turbidity on $\mathrm{pH}$ value $\left(\mathrm{D}_{\mathrm{Fe}}=7 \mathrm{mg} \mathrm{l}^{-1}\right)$.

the surface charge of both kaolinite particles and peptides/proteins and subsequently enable the formation of uncharged micro-aggregates (Fig. 6). Furthermore, kaolinite was also removed within the $\mathrm{pH}$ range $6.5-8$ resulting in low residual turbidity and iron concentrations, but peptides/proteins obviously did not participate in the coagulation process and their residual content remained high. This $\mathrm{pH}$ optimum for removal of kaolinite corresponds to the optimum for coagulation in the test performed only with kaolinite and ferric sulphate (Fig. 2). Moreover, as in the case of coagulation tests with peptides/proteins (Fig. 3), there is a peak of residual iron at a pH of about 6 in Fig. 5. This peak is likely to be caused by two distinct features. Firstly, it can be attributed to the formation of soluble Fe-peptide/protein complexes, similar to the coagulation of peptides/proteins in the absence of kaolinite. Secondly, it may represent the transition between two different processes, i.e. the coagulation of peptides/proteins and kaolinite together at $\mathrm{pH} 4-5.5$ and coagulation of kaolinite itself at $\mathrm{pH} 6.5-8$. Finally, at $\mathrm{pH}>8$, no coagulation occurred due to the excess of the negative charge of all particles in the system - kaolinite, peptides/proteins and also iron constituents.

HPSEC analysis performed after coagulation tests with kaolinite, peptides/proteins and ferric sulphate demonstrated that high-MW proteins are removed under optimal reaction conditions (HPSEC profile at $\mathrm{pH}$ 5), whereas low-MW peptides/proteins remain in the solution (Fig. 7). These peptides/proteins were found to have MW 10, 8.4, 7.7, 6.5, 2.8 and $1 \mathrm{kDa}$. Interestingly, these peptides/proteins were shown by affinity chromatography to form soluble complexes with iron, which is consistent with findings of other studies (Pivokonsky et al. 2009a, 2015; Ma et al. 2012), in which high-MW COM compounds were removed with higher efficiency than low-MW compounds. In addition, only negligible amounts of peptides/proteins were removed during coagulation at $\mathrm{pH} 8$. 


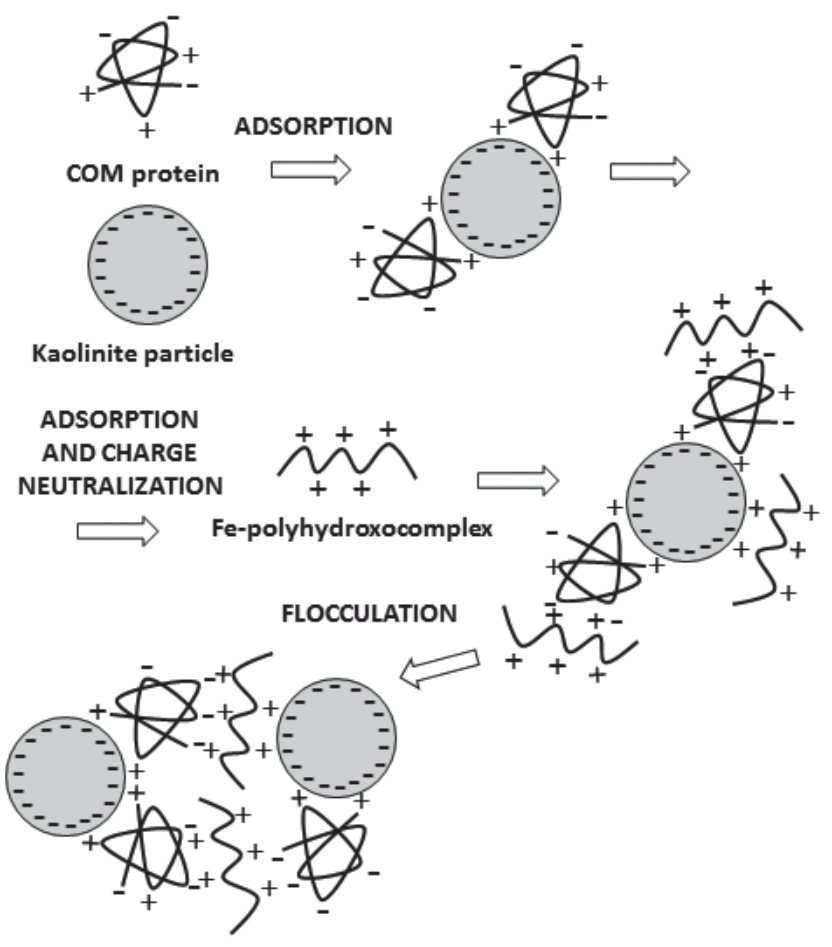

Fig. 6 Mechanism of coagulation of peptides/proteins and kaolinite.

\section{Conclusions}

This research demonstrates that the removal of COM peptides/proteins during water treatment is strongly $\mathrm{pH}$-dependent and that COM peptides/proteins affect the removal of kaolinite particles. The coagulation process is commonly performed at neutral $\mathrm{pH}$ during water treatment. This $\mathrm{pH}$ value is suitable for treatment of highly turbid waters, which is supported by our finding that kaolinite particles are efficiently removed within a $\mathrm{pH}$ range of 6.5 to 8 . Nevertheless, the results of coagulation tests showed that the optimum $\mathrm{pH}$ for COM peptides/ proteins (DOC) removal by ferric sulphate is in the range of 4-6, when electrostatic interactions between positively charged iron constituents and negatively charged sites on peptide/protein molecules enable coagulation through charge neutralization and adsorption. Interestingly, at relatively low $\mathrm{pHs}$ (4-5.5), COM peptides/proteins contribute to the removal of kaolinite. The present findings suggest that during the seasonal growth of cyanobacteria, decrease in reaction $\mathrm{pH}$ is a prerequisite for the efficient removal of COM proteins and is also convenient for clearing turbid water. Regarding peptide/protein characteristics related to coagulation, HPSEC analysis showed that high-MW proteins are effectively removed at optimal reaction $\mathrm{pHs}(4-5.5)$, whereas low-MW proteins are poorly removed. Moreover, it was found that several peptides/proteins are able to form soluble complexes with iron used as a coagulant at a $\mathrm{pH}$ of about 6 . This feature deteriorates the coagulation of COM peptides/proteins and of kaolinite particles.

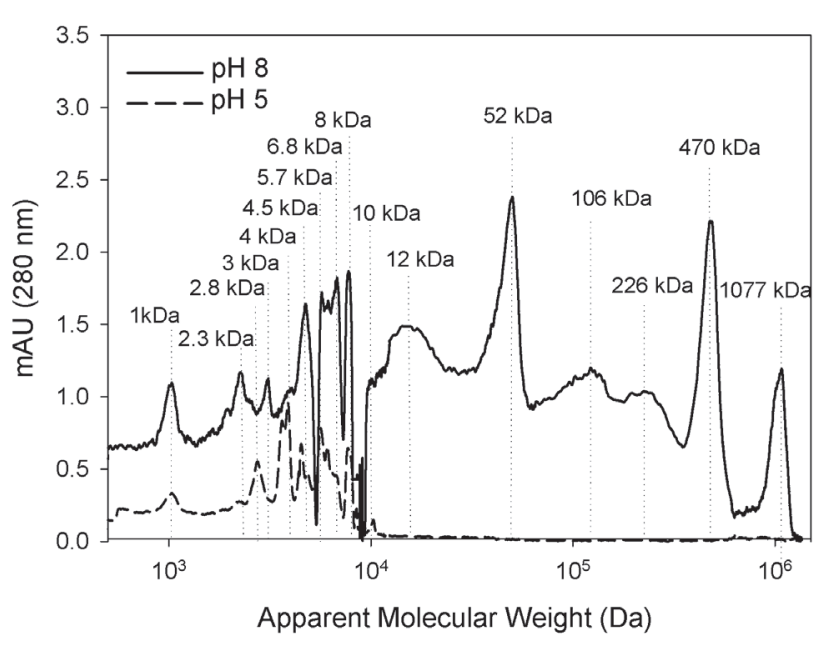

Fig. 7 HPSEC profile of peptides/proteins after coagulation tests at $\mathrm{pH}$ values 8 and 5 .

\section{Acknowledgements}

The authors acknowledge the financial support from specific university research (MSMT No 20-SVV/2016).

\section{REFERENCES}

Albrecht-Gary AM, Crumbliss AL (1998) Coordination chemistry of siderophores: thermodynamics and kinetics of iron chelation and release. In: Sigel A, Sigel H (eds) Metal Ions in Biological Systems - Iron Transport and Storage in Microorganisms, Plants and Animals. Marcel Dekker, New York, pp. 239-327.

Bache DH, Gregory R (2007) Flocks in Water Treatment. IWA Publishing, London.

Bernhardt H, Hoyer O, Shell H, Lüsse B (1985) Reaction mechanisms involved in the influence of algogenic organic matter on flocculation. Z Wasser-Abwasser-Forsch 18: 18-30.

Bratby J (2006) Coagulation and Flocculation in Water and Wastewater Treatment. 2nd ed. IWA Publishing, London.

Campinas M, Rosa MJ (2010) Assessing PAC contribution to the NOM fouling control in PAC/UF systems. Water Res 44: 1636-1644.

Coles CA, Yong RN (2002) Aspects of kaolinite characterization and retention of $\mathrm{Pb}$ and $\mathrm{Cd}$. Appl Clay Sci 22: 39-45.

Dawson RMC, Elliott DC, Elliott WH, Jones KM (1986) Data for Biochemical Research. 3rd ed. Oxford University Press, New York.

Fang J, Yang X, Ma J, Shang C, Zhao Q (2010) Characterization of algal organic matter and formation of DBPs from chlor(am) ination. Water Res 44: 5897-5960.

Harada K-I (2004) Production of secondary metabolites by freshwater cyanobacteria. Chem Pharm Bull 52: 889-899.

Henderson RK, Baker A, Parsons SA, Jefferson B (2008) Characterisation of algogenic organic matter extracted from cyanobacteria, green algae and diatoms. Water Res 42: 3435-3445.

Hnatukova P, Kopecka I, Pivokonsky M (2011) Adsorption of cellular peptides of Microcystis aeruginosa and two herbicides onto activated carbon: effect of surface charge and interactions. Water Res 45: 3359-3368. 
Huang J, Graham N, Templeton MR, Zhang Y, Collins C, Nieuwenhuijsen M (2009) A comparison of the role of two blue-green algae in THM and HAA formation. Water Res 43: 3009-3018.

Kim JS, Kang LS (1998) Investigation of coagulation mechanisms with $\mathrm{Fe}(\mathrm{III})$ salt using jar tests and flocculation dynamics. Environ Eng Res 3: 11-19.

Li L, Gao N, Deng Y, Yao J, Zhang K (2012) Characterization of intracellular \& extracellular algae organic matters (AOM) of Microcystis aeruginosa and formation of AOM-associated disinfection byproducts and odor \& taste compounds. Water Res 46: 1233-1240.

Lüsse B, Hoyer O, Soeder CJ (1985) Mass cultivation of planktonic freshwater algae for the production of extracellular organic-matter (EOM). Z Wasser-Abwasser-Forsch 18: 67-75.

Ma M, Liu R, Liu H, Qu J, Jefferson W (2012) Effects and mechanisms of pre-chlorination on Microcystis aeruginosa removal by alum coagulation: Significance of the released intracellular organic matter. Sep Pur Technol 86: 19-25.

Maksimova IV, Bratkovskaya LB, Plekhanov SE (2004) Extracellular carbohydrates and polysaccharides of the alga Chlorella pyrenoidosa Chick S-39. Biol Bull 31: 175-181.

Pivokonska L, Pivokonsky M, Tomaskova H (2008) Optimization of NOM removal during water treatment. Separ Sci Technol 43: 1687-1700.

Pivokonsky M, Kloucek O, Pivokonska L (2006) Evaluation of the production, composition and aluminum and iron complexation of algogenic organic matter. Water Res 40: 3045-3052.

Pivokonsky M, Polasek P, Pivokonska L, Tomaskova H (2009a) Optimized Reaction Conditions for Removal of Cellular Organic Matter of Microcystis aeruginosa During the Destabilization and Aggregation Process Using Ferric Sulphate in Water Purification. Water Environ Res 81: 514-522.

Pivokonsky M, Pivokonska L, Bäumeltova J, Bubakova P (2009b) The effect of cellular organic matter produced by cyanobacteria Microcystis aeruginosa on water purification. J Hydrol Hydromech 57: 121-129.

Pivokonsky M, Safarikova J, Bubakova P, Pivokonska L (2012) Coagulation of peptides and proteins produced by Microcystis aeruginosa: Interaction mechanisms and the effect of Fe-peptide/protein complexes formation. Water Res 46: 5583-5590.

Pivokonsky M, Naceradska J, Brabenec T, Novotna K, Baresova M, Janda V (2015) The impact of interactions between algal organic matter and humic substances on coagulation. Water Res 84: $278-285$.

Pivokonsky M, Naceradska J, Kopecka I, Baresova M, Jefferson B, Li X, Henderson K (2016) The impact of algogenic organic matter on water treatment plant operation and water quality: A review. Crit Rev Env Sci Technol 46: 291-335.

Pivokonsky M, Safarikova J, Baresova M, Pivokonska L, Kopecka I (2014) A comparison of the character of algal extracellular versus cellular organic matter produced by cyanobacterium, diatom and green alga. Water Res 51: 37-46.

Stumm W, Morgan JJ (1996) Aquatic Chemistry. 3rd ed. John Wiley and Sons, New York.

Takaara T, Sano D, Konno H, Omura T (2007) Cellular proteins of Microcystis aeruginosa inhibiting coagulation with polyaluminum chloride. Water Res 41: 1653-1658.

Takaara T, Sano D, Masago Y, Omura T (2010) Surface-retained organic matter of Microcystis aeruginosa inhibiting coagulation with polyaluminium chloride in drinking water treatment. Water Res 44: 3781-3786.

Tamagnini P, Leitão E, Oliveira P, Ferreira D, Pinto F, Harris D J, Heidorn T, Lindblad P (2007) Cyanobacterial hydrogenases: diversity, regulation and applications. FEMS Microbiol Rev 31: 692-720.

Turner JS, Robinson NJ (1995) Cyanobacterial metallothioneins: biochemistry and molecular genetics. J Ind Microbiol 14: 119-125.

Van Raij BV, Peech M (1972) Electrochemical properties of some oxisols and alfisols of the tropics. Soil Sci Soc Am Pro 36: 587-593.

Xie P, Ma J, Fang J, Guan Y, Yue S, Li X, Chen L (2013) Comparison of Permanganate and Preozonation on Algae Containing Water: Cell Integrity, Characteristics, and Chlorinated Disinfection Byproduct Formation. Environ Sci Technol 47: 14051-14061. 